\title{
Article \\ Effect of Calcium Cyanamide on Soil Fungal Community in Successive Tea-Cuttings Nursery
}

\author{
Qinli Qiu ${ }^{1}{ }^{\oplus}$, Dongmei Fan ${ }^{1}$, Yinmao Wang ${ }^{1}$, Danyi Huang ${ }^{1}{ }^{\oplus}$, Yu Wang $^{1}$, Junhui Ma ${ }^{2}$ and Xiaochang Wang ${ }^{1, *}$ \\ 1 Tea Research Institute, Zhejiang University, \#866 Yuhangtang Road, Hangzhou 310058, China;

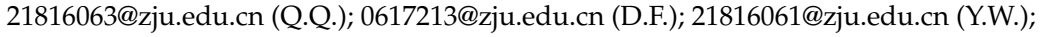 \\ demiwaiting@zju.edu.cn (D.H.); 11616051@zju.edu.cn (Y.W.) \\ 2 Lishui Agricultural Bureau, Lishui 323000, China; 3140100306@zju.edu.cn \\ * Correspondence: xcwang@zju.edu.cn; Tel.: +86-0571-88982380
}

check for updates

Citation: Qiu, Q.; Fan, D.; Wang, Y.; Huang, D.; Wang, Y.; Ma, J.; Wang, X. Effect of Calcium Cyanamide on Soil Fungal Community in Successive Tea-Cuttings Nursery. Agriculture 2021, 11, 716. https://doi.org/ 10.3390/agriculture11080716

Academic Editor: Miguel Soriano

Received: 18 June 2021

Accepted: 26 July 2021

Published: 29 July 2021

Publisher's Note: MDPI stays neutral with regard to jurisdictional claims in published maps and institutional affiliations.

Copyright: (c) 2021 by the authors. Licensee MDPI, Basel, Switzerland. This article is an open access article distributed under the terms and conditions of the Creative Commons Attribution (CC BY) license (https:// creativecommons.org/licenses/by/ $4.0 /)$.

\begin{abstract}
The effects of calcium cyanamide on the soil fungal communities in successive tea-cuttings nursery soils were investigated based on Illumina high-throughput sequencing. The field experiment was carried out with three treatments, including control (CK), flooding (F) and calcium cyanamide (CC). The treatment with calcium cyanamide increased $\mathrm{pH}(\sim 1$ unit) and reduced the accumulation of phenols $(\sim 50 \%)$, available phosphorus $(\sim 28 \%)$ and exchangeable $\mathrm{Al}(\sim 90 \%)$ significantly, and improved soil quality. The predominant phylum in all treatments was Ascomycota. FUNGuild revealed that the dominant trophic mode was saprotrophy in tea-cuttings nursery soil. Plant pathogens had a low abundance in the calcium cyanamide treatment. Alpha diversity analysis showed lower richness in the calcium cyanamide than the other treatments. Network analysis showed a poorly connected but highly modularized network in the calcium cyanamide treatment, with the crucial OTUs functions related to anti-pathogenicity. The results showed that calcium cyanamide should be recommended for improving long-term tea nurseries by increasing the survival rate of tea seedlings due to increasing soil $\mathrm{pH}$ value, reducing aluminum toxicity, decreasing the accumulation of polyphenols, diminishing pathogenic fungi and making the taxa related to anti-pathogenicity occupy a more important niche.
\end{abstract}

Keywords: calcium cyanamide; successive tea-cuttings nursery; fungal community composition; molecular ecological network; FUNGuild

\section{Introduction}

Tea (Camellia sinensis L.) is a major and monetarily important crop in China. In recent years, both the area and yield have increased rapidly. As a result, there is a large requirement for tea nurseries. However, soil degradation and acidification are significant obstacles during the long-term monoculture of tea plants, thereby limiting tea seedling survival rate [1-3]. Soil acidification induced by growing tea or breeding tea seedling increases soil exchangeable $\mathrm{Al}$ and soluble $\mathrm{Al}$ concentrations and phenol accumulation, resulting in Al toxicity and accretion of phenols in tea soil [4-7]. The stimulation of soil-borne pathogens, deterioration of soil physical and chemical properties, and the accumulation of autotoxic substances were the common problems associated with monoculture $[1,8]$. These phenomena have also been observed in annual crops, such as cotton, potato and cucumber [8-10]; also in perennial plants, such as apple, peach and sugarcane [11-13]. In view of the widespread problems in the long-term cropping soils, the common ameliorating measures are reducing fertilization, applying organic fertilizers, adding chemical conditioners such as biochar, etc. Considering particularly tea nurseries, we chose calcium cyanamide and flooding as the means to improve the soil.

As a nitrogenous fertilizer, calcium cyanamide $\left(\mathrm{CaCN}_{2}\right)$ was usually utilized in the field and greenhouse production of vegetables [14]. Recent Chinese and Japanese researches focused more on the application of calcium cyanamide in oilseed rape, vegetable 
and tea crops [15-17]. Calcium cyanamide was found to have fungicidal, insecticidal, nematicidal, and herbicidal properties [18]. It releases nitrogen slowly, enhances soil fertility and helps diminish the infestation of the soil with soil-borne pathogens and weeds [16]. Additionally, many studies about calcium cyanamide as a plant growth regulator have been performed, such as break the natural dormancy of apple and grape, regulate flowering $[19,20]$. Calcium cyanamide is an environmentally benign product, it has negligible impact on the environment because it does not leave residues in soil and is not poisonous to animals $[14,18]$. It could be broken down into harmless products by microbes (such as some Aspergillus and Penicillium spp.) [14,21]. Calcium cyanamide can increase some enzymatic activity of the soil, including protease, amylase, invertase, dehydrogenase and alkaline phosphatase activities, which finally encourages soil microbial activity $[14,21,22]$. Instead, it can decrease urease activity in soil, resulting in a lower hydrolysis rate and nutrient release rate of urea, and ultimately reduce nitrogen loss [19]. In agricultural soils, it is often used to ameliorate soil acidification, increase nitrogen utilization rate, and control soil-borne diseases $[16,18,23]$.

Short-term soil flooding is the method used to kill aerobic pathogens in soil by creating a strong reducing environment (anaerobic soil). The effect of flooding or a combination of flooding treatment and organic materials on overcoming obstacles associated with continuous cropping caused by soil-borne diseases has been well verified in short-term crops or greenhouse-potted plants [24,25].

Fungi are the primary decomposers and carbon sequesters in soils and agroecosystems [26,27]. They are beneficial for plant growth, crop production and crop protection [28]. Fungi could decompose different polymers by producing extra-cellular enzymes [29]. In addition, fungi are also associated with the degradation of protein-like materials [30]. Compared to bacteria, fungi are well adjusted with soil $\mathrm{pH}$ and can normally survive in an environment with a range $\mathrm{pH}(5-9)$ without significantly hindering growth [31]. FUNGuild is an ecological guild independent of sequencing platform or analysis pipeline, which can be used as a tool for fungal OTUs classification and analysis [32]. Many known functions of fungi are mediated by specific guilds [33]. Pathotrophic fungi commonly attack host cells to obtain nutrients, and usually have negative effects on plant performance [34]. Some symbiotrophic fungi could benefit crops regarding quality, health and nutrition $[35,36]$. The saprotrophic fungi are generally recognized as critical decomposers of soil organic matter, which derive nutrients by decomposing dead host cells [37].

The changes in tea soil microbial communities have been investigated in previous studies. As a result, many researchers have found that the soil fungal community will be altered by long-term tea cropping, and this alteration could have negative impacts on tea growth and yield [38]. Although the application of calcium cyanamide and flooding is widespread and the vitality of fungi in terrestrial ecosystem processes is well acknowledged, there are seldom researches on the response of soil fungi in the tea-cuttings nursery to flooding and calcium cyanamide applications. The targets of this study were to (1) explore the alteration of physiochemical properties in the successive tea-cutting nursery soils after treatment with flooding or calcium cyanamide, (2) explore the reaction of fungal community structure, composition and function to the changes in physiochemical soil properties, and (3) evaluate flooding and calcium cyanamide as methods for improving successive tea nursery soils and the survival rate of tea seedlings.

\section{Materials and Methods}

\subsection{Sample Collection}

The sampling site was situated at Da Gangtou Town (28.30 N, 117.75 E) in Liandu District, Lishui City, Zhejiang Province. The chosen tea-cuttings nursery is used for cultivating tea seedlings. Before the experiment, the soil properties were $\mathrm{pH} 4.98$, total phenols (TP) $7546.46 \mathrm{mg} / \mathrm{kg}$, bound phenols (BP) $861.94 \mathrm{mg} / \mathrm{kg}$, available potassium (AK) $39.38 \mathrm{mg} / \mathrm{kg}$, available phosphorus (AP) $101.50 \mathrm{mg} / \mathrm{kg}$, soil organic carbon (SOC) $15.17 \mathrm{~g} / \mathrm{kg}$ and total nitrogen $(\mathrm{TN}) 2.04 \mathrm{~g} / \mathrm{kg}$. Tea seedlings used in the experiment were raised from cuttings in 
December 2018. The spikes used for cuttings were $3 \pm 0.3 \mathrm{~cm}$ long, with one bud and one leaf. The cuttings density was about 4,200,000 per hectare. Three treatments were applied in October 2018 (each treatment was set in triplicate, with each replicate plot measuring $40 \mathrm{~m}^{2}$ ): (1) control (labeled " $\mathrm{CK}$ "); (2) flooding (labeled " $\mathrm{F}$ "), flooding for a month before cutting; the depth of flooding was 10-15 cm above soil surface; and (3) calcium cyanamide (labeled "CC"); calcium cyanamide was applied at a rate of $350 \mathrm{~kg} / \mathrm{ha}$ to a depth of $10 \mathrm{~cm}$; then, the soil was plowed, leveled and irrigated to field capacity. Afterwards, we covered the soil with transparent polyethylene sheets for 30 days for the treatments, and the edges of the plastic were covered with $20 \mathrm{~cm}$ height of soil to prevent gas exchange [18].

The soil samples were collected in September 2019. The soil samples in each plot $(0-20 \mathrm{~cm}$ depth after removing any litter from the surface) were collected at five points along an " $\mathrm{S}$ " shape and thoroughly mixed. After sieving (10-mesh), we divided every soil sample into two parts, and quickly sent one part to the lab (surrounded by ice bags during transportation) and stored at $-80^{\circ} \mathrm{C}$ for Illumina sequencing. The other part was air-dried and sieved through 20-mesh and 60-mesh sieves for determining soil physiochemical properties.

\subsection{Soil Physicochemical Properties}

The $\mathrm{pH}$ was measured using a calibrated glass electrode (E-201-C type) in a 1:2.5 of soil: $\mathrm{H}_{2} \mathrm{O}$ suspension. Soil organic carbon (SOC) was determined using the dichromate sulfuric acid method [39]. Total nitrogen (TN) was measured by the Kjeldahl digestion procedure [7]. Ammonium nitrogen $\left(\mathrm{NH}_{4}{ }^{+}-\mathrm{N}\right)$ and nitrate nitrogen $\left(\mathrm{NO}_{3}{ }^{-}-\mathrm{N}\right)$ were measured according to NY/T 1849-2010 and GB/T 32737-2016, respectively. Briefly, $\mathrm{NH}_{4}{ }^{+}-\mathrm{N}$ was extracted by combined extraction which is composed of $\mathrm{NaF}(0.015 \mathrm{M}), \mathrm{Na}_{2} \mathrm{SO}_{4}(0.025 \mathrm{M}), \mathrm{CH}_{3} \mathrm{COONa}$ $(0.2 \mathrm{M})$ and disodium EDTA $(0.001 \mathrm{M})$ and measured by spectrophotometric method. $\mathrm{NO}_{3}{ }^{-}$-N was extracted by $1 \mathrm{M} \mathrm{KCl}$ and determined by spectrophotometric method with a correction factor. Available phosphorus (AP) was extracted by sodium bicarbonate and measured via molybdenum antimony colorimetry method [7]. Available potassium (AK) was extracted by $1 \mathrm{M}$ ammonium acetate (according to LY/T 1235-1999) and measured by flame photometry. Exchangeable aluminum (Ex-Al) and acid-soluble aluminum (Col$\mathrm{Al})$ were extracted by $\mathrm{KCl}(1 \mathrm{M})$ and $\mathrm{HCl}(1 \mathrm{M})$, respectively, and measured by flame photometry [4]. Total phenols (TP) and bound phenols (BP) were determined by the modified Folin-Ciocalteu method [7,40].

\subsection{Soil DNA Extraction, PCR Amplification and Illumina Sequencing}

Soil DNA was extracted by a DNeasy Powersoil kit (QIAGEN, Germany). NanoDrop 2000 UV-vis spectrophotometer (Thermo Scientific, Wilmington, DE, USA) was used to determine the final DNA concentration and purification. In addition, DNA quality was checked by $1 \%$ agarose gel electrophoresis. Each of the 15 DNA samples (3 treatments $\times 5$ ) was amplified by a pair of barcode specific primers (ITS1F:5'-CTTGGTCATTTAGAGGAAG TAA-3', ITS2R:5'-GCTGCGTTCTTCATCGATGC-3') [41] by thermocycler PCR system (GeneAmp 9700, ABI, Waltham, MA, USA). The PCR reactions were performed using the following procedure: $3 \mathrm{~min}$ of denaturation at $95^{\circ} \mathrm{C}, 27$ cycles of $30 \mathrm{~s}$ at $95^{\circ} \mathrm{C}, 30 \mathrm{~s}$ for annealing at $55^{\circ} \mathrm{C}$, and $45 \mathrm{~s}$ for elongation at $72{ }^{\circ} \mathrm{C}$, and the last extension at $72{ }^{\circ} \mathrm{C}$ for $10 \mathrm{~min}$. The total $20 \mu \mathrm{L}$ PCR reaction system contains $4 \mu \mathrm{L}$ of $5 \times$ FastPfu Buffer, $2 \mu \mathrm{L}$ of $2.5 \mathrm{mM}$ dNTPs, $0.8 \mu \mathrm{L}$ of each primer $(5 \mu \mathrm{M}), 0.4 \mu \mathrm{L}$ of FastPfu Polymerase, and $10 \mathrm{ng}$ of template DNA. Then, $2 \%$ agarose gel was adopted to extract PCR products, following the AxyPrep DNA Gel Extraction Kit (Axygen Biosciences, Union City, CA, USA) and QuantiFluor ${ }^{\mathrm{TM}}$-ST (Promega, Madison, WI, USA) were used to purify and quantify the PCR products according to the manufacturer's recommendations, respectively. The purified PCR products were sequenced on the Illumina MiSeq platform (Illumina, San Diego, CA, USA) according to the standard protocols by Majorbio Bio-Pharm Technology Co. Ltd (Shanghai, China). 


\subsection{Data Analysis}

Statistically significant differences in soil properties among the treatments were determined using one-way ANOVA, along with the Duncan test for multiple comparisons in SPSS (version 25.0). Raw fastq files were quality-filtered by Trimmomatic and merged by FLASH software (version 1.2.11). Operational taxonomic units (OTUs) were clustered with $97 \%$ similarity cutoff using UPARSE (version 7.0.1090) with a novel "greedy" algorithm that performs chimera filtering and OTU clustering simultaneously. Species annotation was performed to compare the OTU sequences with those in the fungal ITS database (http:/ / unite.ut.ee/index.php, accessed on 29 July 2021) in UNITE (version 8.0).

Alpha diversity was adopted to evaluate the richness and diversity of fungi according to five indices: the Shannon, Chao1, ACE, Simpson, Coverage. Mothur software (version 1.30.2) was used to calculate these indices. Box plots of alpha diversity were drawn by Origin software (version 2018). Among soil samples, dissimilarities in fungi community composition were calculated based on Bray-Curtis distance matrices. Afterwards, principal coordinate analysis (PCoA) and a hierarchical tree were used for ordination. RDA analysis was based on vegan package in $R$. The correlation heatmap plot was analyzed in pheatmap package in $\mathrm{R}$.

Additionally, fungal networks were separately constructed for each treatment based on the MENAP website (http: / /ieg4.rccc.ou.edu/mena / main.cgi, accessed on 29 July 2021) according to the developer's instructions [42,43]. Firstly, the standardized OTU tables in the three treatments were prepared. Secondly, we submitted the OTU tables to the MENA website and the correlations between the OTUs were obtained. Thirdly, an appropriate threshold was chosen for defining network structure according to the RMT-based network approach [43]. Finally, employing Cytoscape software (version 3.7.1) and Origin software (version 2018), all the networks and Z-P plots were drawn, respectively.

FUNGuild (version 1.0) was adopted to analyze the fungal guilds. The original OTU table sorted by sequencing abundance was outputted, including the trophic mode, guild and confidence data. To avoid over-interpretation of the results, only the probable and highly probable results were selected for analysis. Function predictions were achieved as stated by the descriptions detailed elsewhere.

\section{Results}

\subsection{General Characteristics of Soil Properties}

The results showed that the $\mathrm{pH}$ value, $\mathrm{AK}$ and $\mathrm{NO}_{3}{ }^{-}-\mathrm{N}$ contents were significantly higher in the CC than in the CK treatment (Table 1). The contents of TP, BP, SOC, and Ex-Al were significantly lower in the CC compared with the CK treatment. Similarly, the AP content also showed a decreasing trend. The $\mathrm{NH}_{4}{ }^{+}-\mathrm{N}$ and Col-Al contents in the CC treatment were not significantly different from the CK treatment.

Table 1. Physical and chemical properties of the soil from the control, flooding and calcium cyanamide treatments in tea nursery.

\begin{tabular}{|c|c|c|c|c|c|c|c|c|c|c|c|}
\hline Treatment & $\mathrm{pH}$ & $\begin{array}{c}\text { TP } \\
(\mathrm{mg} / \mathrm{g})\end{array}$ & $\begin{array}{c}\text { BP } \\
(\mathrm{mg} / \mathrm{g})\end{array}$ & $\begin{array}{c}\mathrm{AP} \\
(\mathrm{mg} / \mathrm{kg})\end{array}$ & $\begin{array}{c}\text { AK } \\
(\mathrm{mg} / \mathrm{kg})\end{array}$ & $\begin{array}{c}\text { Ex-Al } \\
(\mathrm{mg} / \mathrm{kg})\end{array}$ & $\begin{array}{l}\text { Col-Al } \\
\text { (g/kg) }\end{array}$ & $\begin{array}{c}\text { SOC } \\
(\mathrm{g} / \mathrm{kg})\end{array}$ & $\begin{array}{c}\text { TN } \\
(\mathrm{g} / \mathrm{kg})\end{array}$ & $\begin{array}{c}\mathrm{NO}_{3}--\mathrm{N} \\
(\mathrm{mg} / \mathrm{kg})\end{array}$ & $\begin{array}{c}\mathrm{NH}_{4}{ }^{+}-\mathrm{N} \\
(\mathrm{mg} / \mathrm{kg})\end{array}$ \\
\hline CK & $\begin{array}{c}3.96 \pm \\
0.04 \mathrm{a}\end{array}$ & $\begin{array}{c}10.06 \pm \\
0.45 \mathrm{c}\end{array}$ & $\begin{array}{l}1.10 \pm \\
0.04 \mathrm{~b}\end{array}$ & $\begin{array}{c}212.27 \pm \\
4.21 \mathrm{~b}\end{array}$ & $\begin{array}{c}218.28 \pm \\
16.25 \mathrm{a}\end{array}$ & $\begin{array}{c}180.99 \pm \\
1.30 \mathrm{c}\end{array}$ & $\begin{array}{c}3.11 \pm \\
0.02 \mathrm{a}\end{array}$ & $\begin{array}{c}21.76 \pm \\
0.05 \mathrm{~b}\end{array}$ & $\begin{array}{l}2.43 \pm \\
0.006 \mathrm{~b}\end{array}$ & $\begin{array}{l}62.77 \pm \\
0.064 \mathrm{a}\end{array}$ & $\begin{array}{c}38.37 \pm \\
0.32 \mathrm{a}\end{array}$ \\
\hline $\mathrm{F}$ & $\begin{array}{c}4.07 \pm \\
0.01 \mathrm{a}\end{array}$ & $\begin{array}{c}8.80 \pm \\
0.15 \mathrm{~b}\end{array}$ & $\begin{array}{l}1.16 \pm \\
0.01 \mathrm{~b}\end{array}$ & $\begin{array}{c}157.64 \pm \\
6.88 \mathrm{a}\end{array}$ & $\begin{array}{c}292.22 \pm \\
3.88 \mathrm{ab}\end{array}$ & $\begin{array}{c}152.17 \pm \\
2.31 \mathrm{~b}\end{array}$ & $\begin{array}{c}3.04 \pm \\
0.66 \mathrm{a}\end{array}$ & $\begin{array}{c}22.08 \pm \\
0.07 \mathrm{~b}\end{array}$ & $\begin{array}{l}2.47 \pm \\
0.006 \mathrm{c}\end{array}$ & $\begin{array}{l}69.06 \pm \\
0.055 \mathrm{~b}\end{array}$ & $\begin{array}{c}42.1 \pm \\
0.1 \mathrm{~b}\end{array}$ \\
\hline $\mathrm{CC}$ & $\begin{array}{l}4.93 \pm \\
0.08 \mathrm{~b}\end{array}$ & $\begin{array}{l}5.50 \pm \\
0.002 \mathrm{a}\end{array}$ & $\begin{array}{c}0.981 \pm \\
0.05 \mathrm{a}\end{array}$ & $\begin{array}{l}154 \pm \\
2.38 \mathrm{a}\end{array}$ & $\begin{array}{c}303.29 \pm \\
42.23 \mathrm{~b}\end{array}$ & $\begin{array}{c}20.66 \pm \\
3.88 \mathrm{a}\end{array}$ & $\begin{array}{c}2.59 \pm \\
0.10 \mathrm{a}\end{array}$ & $\begin{array}{c}20.30 \pm \\
0.27 \mathrm{a}\end{array}$ & $\begin{array}{l}2.38 \pm \\
0.006 \mathrm{a}\end{array}$ & $\begin{array}{r}76.94 \pm \\
0.055 \mathrm{c}\end{array}$ & $\begin{array}{c}38 \pm 0.1 \\
\mathrm{a}\end{array}$ \\
\hline
\end{tabular}

Different letters in the same column indicate significant differences among the three treatments at $p<0.05$. 
At the end of the cutting period, we found that both F and CC treatments increased the survival rate of tea seedlings, especially the CC treatment that generated values close to those in the non-successive tea nursery (Table 2).

Table 2. The survival rate in different tea nurseries.

\begin{tabular}{cc}
\hline & Survival Rate (\%) \\
\hline CK & 69.64 \\
F & 82.64 \\
CC & 83.65 \\
Non-successive tea nursery & 86.97 \\
\hline
\end{tabular}

\subsection{Assessment of Sequencing Data}

A dataset of 1,076,411 quality sequences was generated from all soil samples. As Figure 1A shows, the rarefaction curves of all the samples flattened, and it indicated that the sequencing depth in this study was sufficient to reflect the fungal communities' composition in various treatments and the results were reliable. Furthermore, the coverage index values in all samples exceeded $99.5 \%$ (see Table S1), also proving the above results. A total of 2787 operational taxonomic units (OTUs) were clustered based on $97 \%$ similarity. According to the OTU-Venn graph, there were 1880, 1810 and 1713 OTUs in total in soil samples from CK, F and CC, respectively (Figure 1B). What is more, there were $987 \mathrm{common}$ OTUs in soil samples. The numbers of unique OTUs in CK, F and CC were 438, 347 and 373 , respectively.
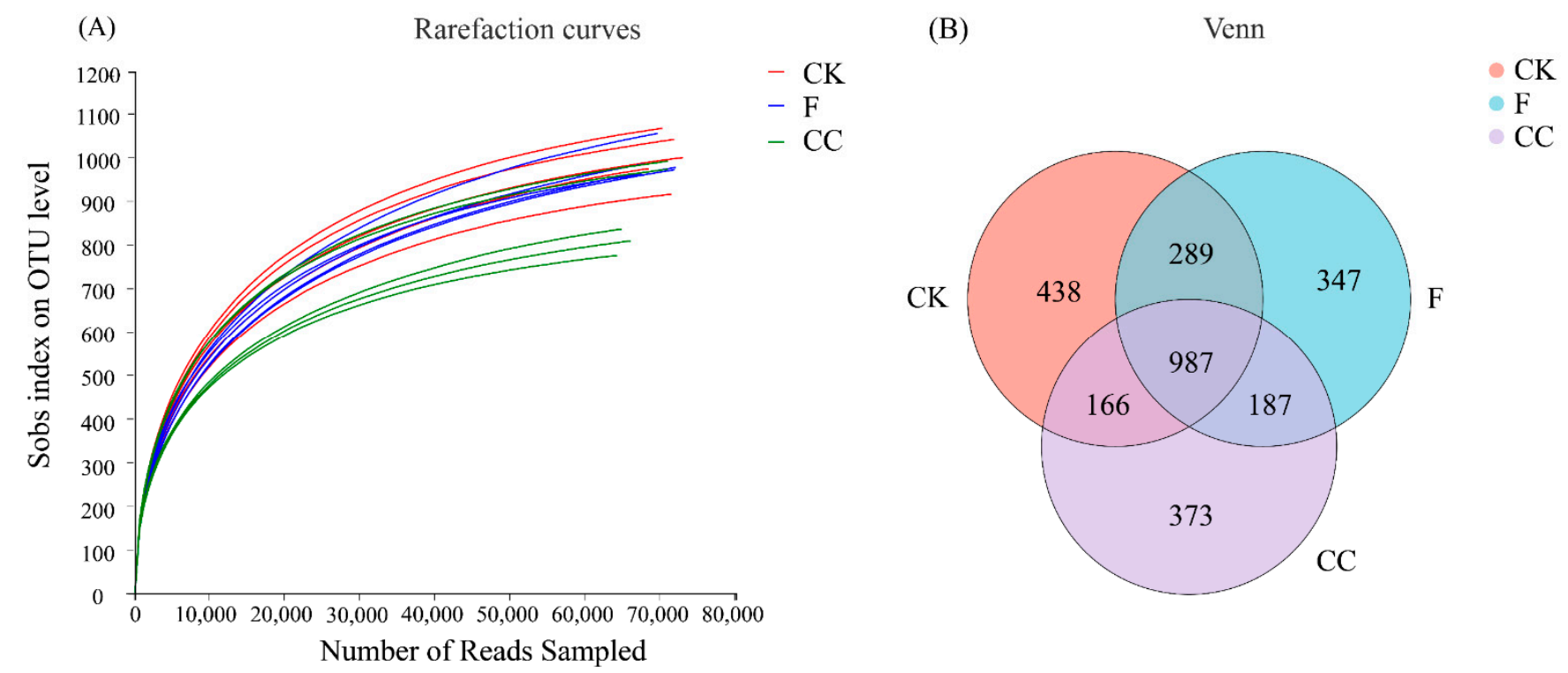

Figure 1. (A) Rarefaction curves of tea nursery soil samples and (B) Venn diagram of the control (CK), flooding (F) and calcium cyanamide (CC) treatments in tea nursery.

\subsection{Alpha Diversity Analysis}

Comparing the alpha diversity of the fungal communities among the three tea nursery soil samples (Figure 2), the ACE and Chao 1 index values (estimating the richness) were significantly lower in the CC than the other treatments, however, no significant difference was observed between the CK and F treatments. Additionally, Shannon and Simpson index values (estimating the diversity) were similar among the three treatments. 

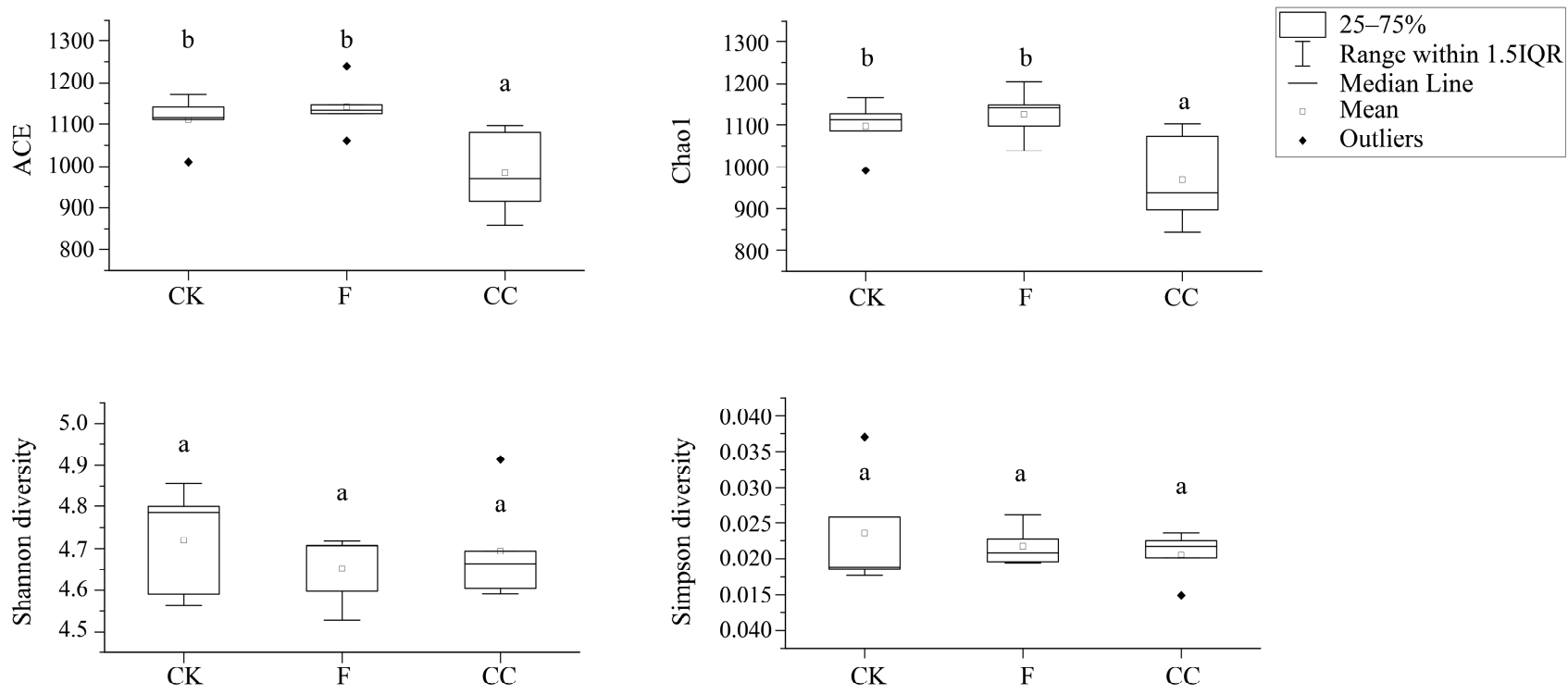

Figure 2. Box plot of alpha diversity indices of the fungal communities in tea nursery soil. Different letters indicate significant differences between the three treatments (control $(\mathrm{CK})$, flooding $(\mathrm{F})$ and calcium cyanamide $(\mathrm{CC})$ at $p<0.05)$.

\subsection{Fungal Community Structure and Composition}

Principal coordinate analysis (PCoA) based on the Bray-Curtis measure revealed different patterns in the fungal communities of the three types of tea soil samples (CK, F, $\mathrm{CC}$ ), with the first two axes explaining $35.3 \%$ and $31.96 \%$ of the total variation (Figure $3 \mathrm{~A}$ ). The linkage hierarchical clustering analysis (Bray-Curtis dissimilarity) further confirmed that the fungal patterns in F and CC were separated from CK (Figure 3B), indicating that the two treatments considerably shifted soil fungal community composition.

(A)

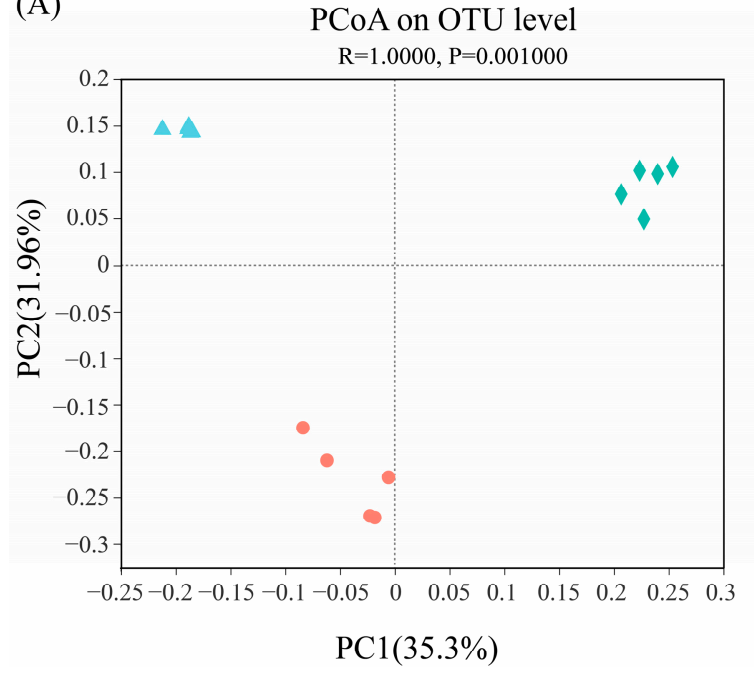

(B)

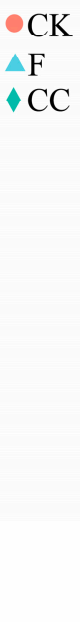

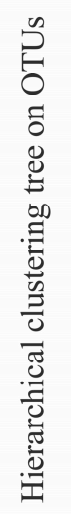

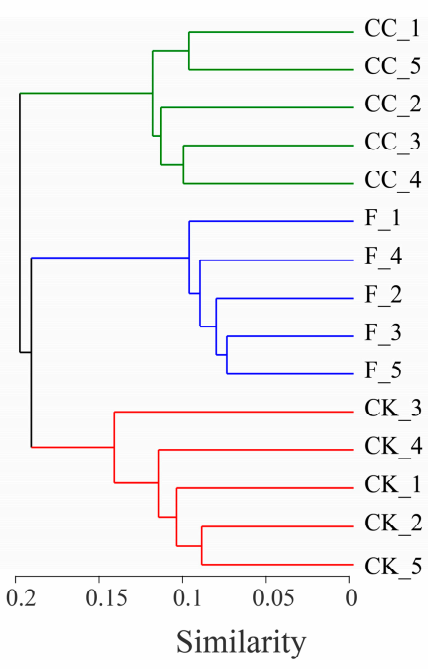

Figure 3. (A) Principal coordinate analysis (PCoA) and (B) hierarchical cluster tree of fungal community in tea nursery soil samples.

High-throughput sequencing identified 15 phyla, 50 classes, 116 orders, 261 families, and 524 genera in 15 tea nursery soil samples. A similar composition of soil fungal community among the three treatments was observed, but the relative abundances were obviously different. At the phylum level (Figure $4 \mathrm{~A}, \mathrm{C}$ ), the fungal community was dominated by Ascomycota. The relative abundances of Ascomycota in the CK, F and CC samples were $74.27 \%, 56.72 \%$ and $83.28 \%$, respectively. The next most abundant phylum in the CK and the F treatments was Basidiomycota $(9.45 \%$ and $18.83 \%)$, while in the CC it was Rozellomycota 
(5.62\%). The relative abundance of Basidiomycota was significantly higher in the $\mathrm{F}$ than in the CK treatment. With respect to the relative abundance of phylum Mortierellomycota, CC showed the lowest value (2.89\%), while CK and F showed a similar value (nearly $5.5 \%$ ). The relative abundance of Chytridiomycota was reduced to almost zero after the treatment with flooding or calcium cyanamide, while it was about $2.49 \%$ in the CK. At the genus level (Figure 4B,D), Trichoderma, Mortierella, unclassified_c_Sordariomycetes and Derxomyces were the dominant genera in CK, accounting for 7.32\%, 5.38\%, 5.37\%, 5.09\%, respectively. In the F treatment, unclassified_o_GS11 and Derxomyces were the significant dominant genera, accounting for $14.36 \%$ and $12.77 \%$, respectively. The dominant genera in the CC treatment were Talaromyces, Emericellopsis and unclassified_c_Sordariomycetes, accounting for $8.41 \%$, $7.72 \%$ and $5.44 \%$, respectively.

(A)

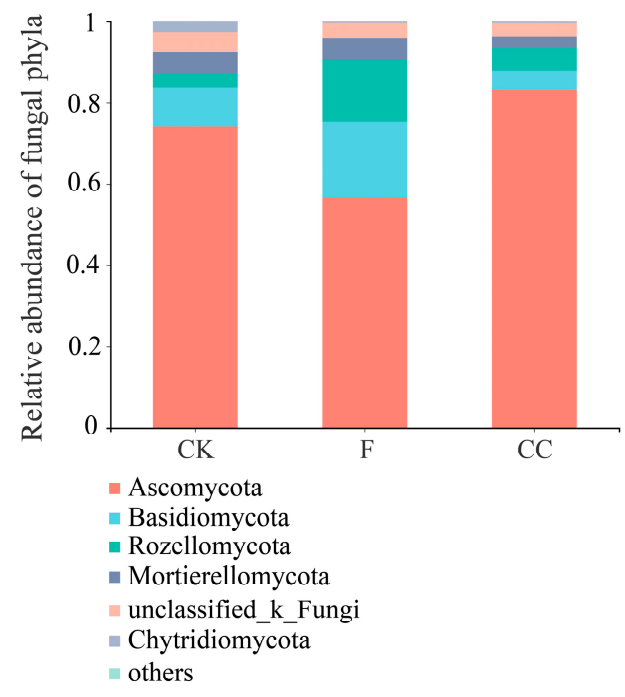

(C)

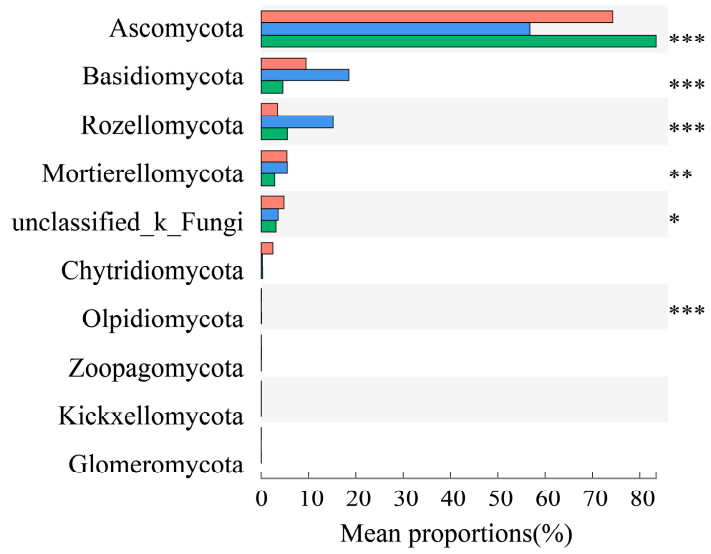

(B)

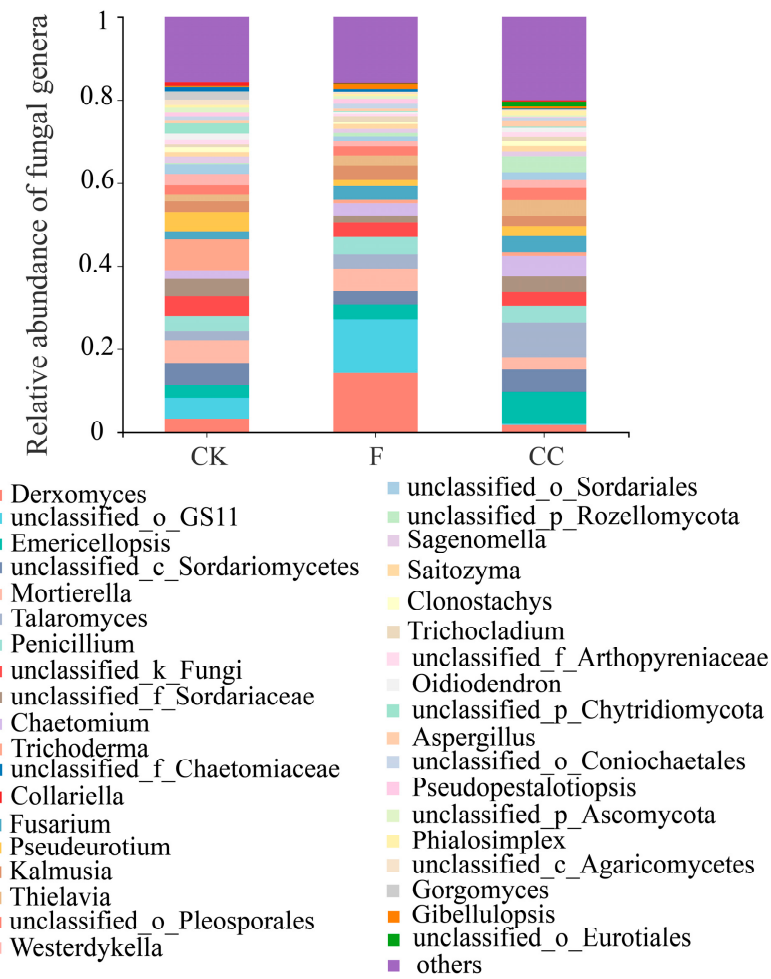

(D)

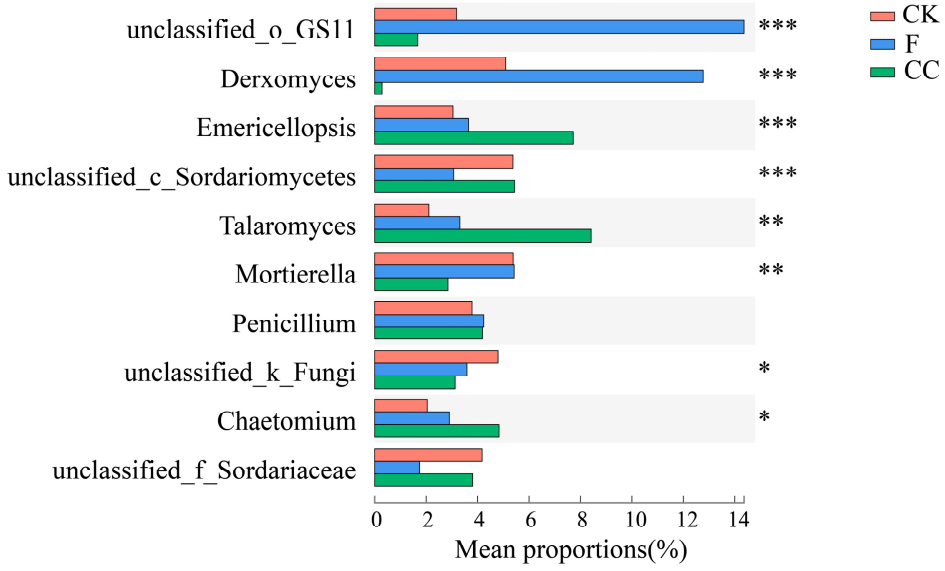

Figure 4. The relative abundance of top fungal phyla (A) and genera (B), and comparison of top 10 fungal phyla (C) and genera (D) using One-Way ANOVA analysis in different treatments in tea nursery. The significant differences are denoted by asterisks $\left({ }^{*} p<0.05\right.$; ${ }^{* *} p<0.01$; $\left.{ }^{* * *} p<0.001\right)$. 


\subsection{Correlation among Soil Physicochemical Properties and Abundance of Fungal Taxa}

Redundancy analysis (RDA) results of the soil fungal communities are shown in Figure 5A. Of the total variance, $86.06 \%$ and $4.87 \%$ were explained by the first two RDA axes. Ascomycota was positively associated with $\mathrm{AK}$ and $\mathrm{pH}$, and negatively associated with Col-Al, TN, BP, SOC, Ex-Al, and TP. Conversely, Basidiomycota was positively associated with Col-Al, TN, BP, SOC, Ex-Al, and TP, and significantly negatively associated with AK and $\mathrm{pH}$. Rozellomycota was negatively associated with AP.

(A)

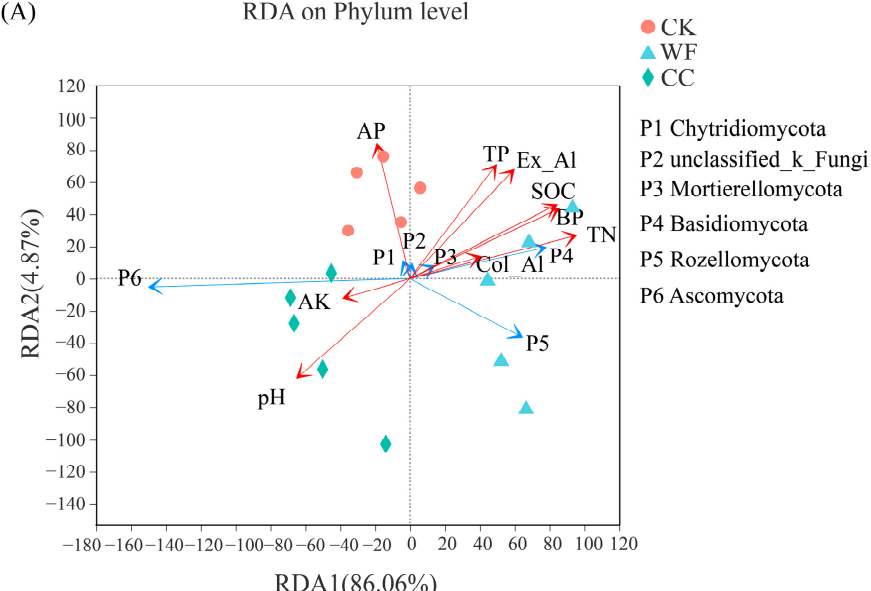

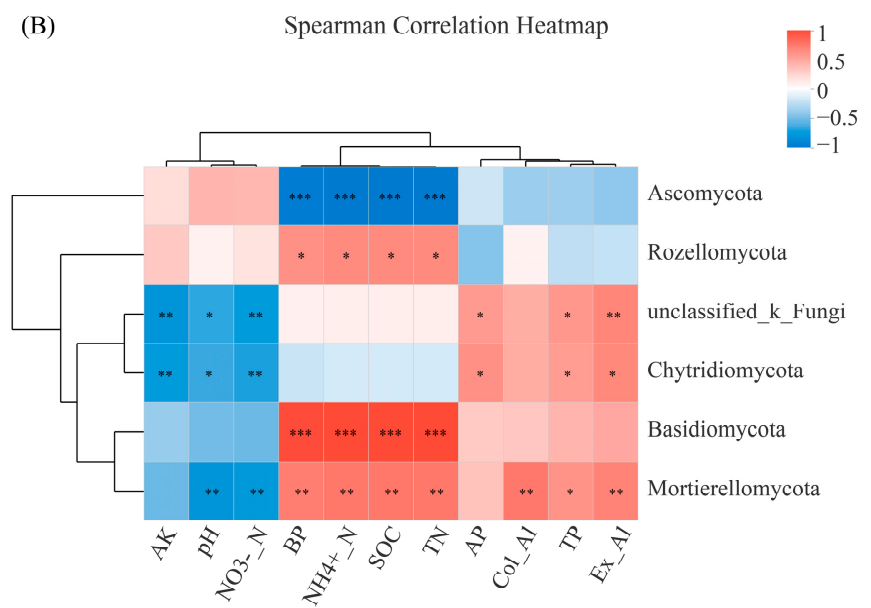

Figure 5. (A) Redundancy analysis (RDA) of the abundant fungal phyla and soil physicochemical characteristics. (B) The heatmap based on Spearman's correlation analysis between fungal phyla and physicochemical variables. The significant correlations are denoted by asterisks $\left({ }^{*} p<0.05 ;{ }^{* *} p<0.01 ;{ }^{* *} p<0.001\right)$.

The Spearman's correlation between physicochemical characteristics of soil samples and fungal phyla abundance was evaluated and visualized in a heatmap (Figure $5 \mathrm{~B}$ ). The Ascomycota abundance showed a significantly negative correlation with $\mathrm{BP}, \mathrm{NH}_{4}{ }^{+}-\mathrm{N}$, SOC, and TN, whereas the abundance of Basidiomycota, Rozellomycota and Mortierellomycota was positively associated with these four physicochemical properties. In addition, the Mortierellomycota abundance had a significantly positive relationship with Col-Al, TP and Ex-Al, and a negative relationship with $\mathrm{pH}$ and $\mathrm{NO}_{3}{ }^{-}-\mathrm{N}$. In summary, $\mathrm{BP}, \mathrm{NH}_{4}{ }^{+}-\mathrm{N}, \mathrm{SOC}$, and $\mathrm{TN}$ were the physiochemical properties with the most significant influences on the abundance of fungal phyla.

\subsection{Molecular Ecological Network Analysis}

To obtain a more particular knowledge of the interactions in the tea nursery soil fungal communities, three types of molecular ecological networks (pMENs) were constructed as shown in Figure 6. Moreover, Table 3 shows the ecological network indices. In total, 100 random networks were further performed to each empirical network and in terms of the average clustering coefficient, average path distance and modularity, significant differences between the three empirical networks and their corresponding random networks were observed (Table 3). Average connectivity (avgK, from 10.10 to 12.43), as a measure of the complexity of a network, indicated that the CC treatment generated a less complex network than the CK and F treatments. Conversely, the average path distance (GD) was highest in the CC treatment, revealing the most distant relationships in that treatment. 
(A)

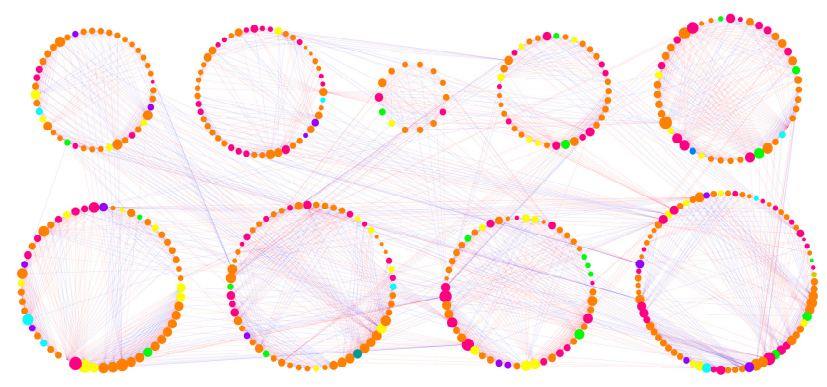

(B)

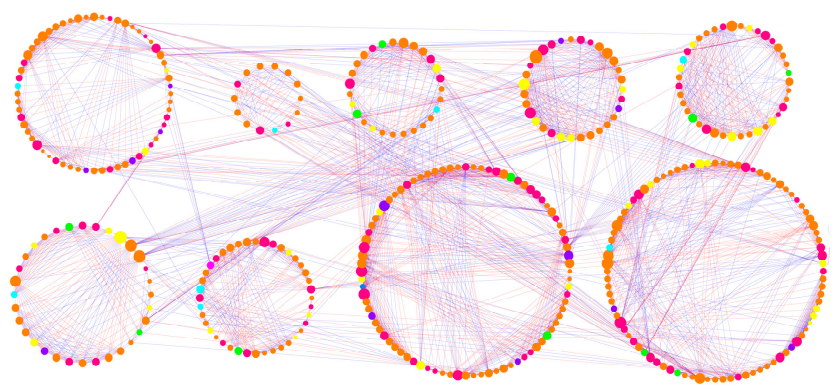

(C)
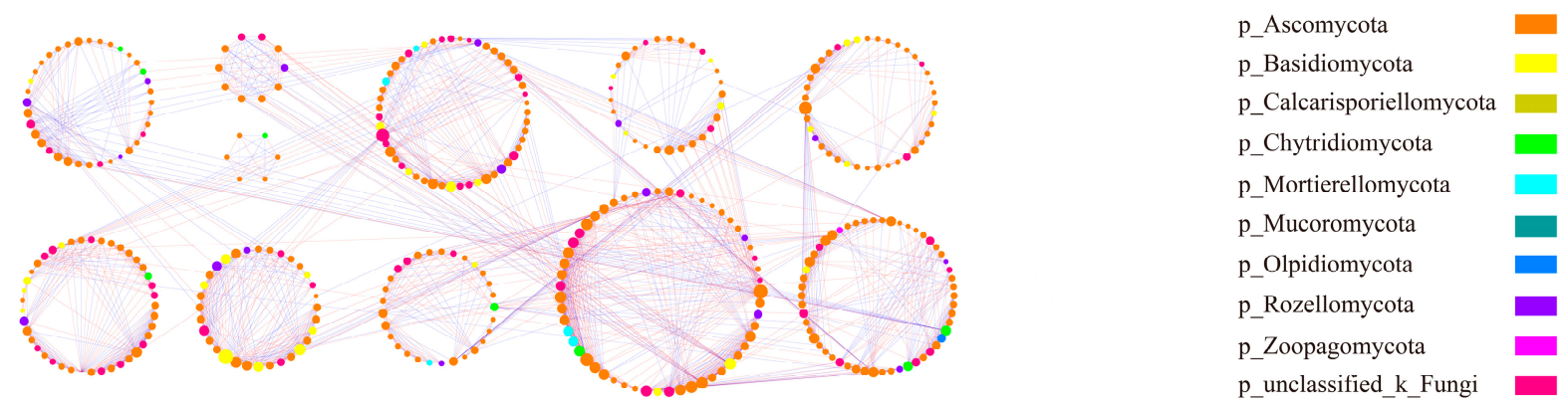

Figure 6. Ecological network graph of CK (A), F (B), and CC (C) treatments. Nodes' colors represent the different phyla. The red edges represent a positive relationship between two nodes, and blue ones show a negative interaction. The size of nodes indicates the size of node degree.

Table 3. Major topological properties of the empirical molecular ecological networks (MENs) of the microbial communities and their associated random MENs.

\begin{tabular}{cccccccccc}
\hline & \multicolumn{3}{c}{ Empirical Networks } & & \multicolumn{2}{c}{ Random Networks } \\
\hline $\begin{array}{c}\text { Treatment } \\
\begin{array}{c}\text { Similarity } \\
(S t)\end{array}\end{array}$ & $\begin{array}{c}\text { Network } \\
\text { Size }(n)\end{array}$ & $\begin{array}{c}\text { Average } \\
\text { Connectiv- } \\
\text { ity } \\
(\text { avgK) }\end{array}$ & $\begin{array}{c}\text { Average } \\
\text { Clustering } \\
\text { Coefficient } \\
\text { (avgCC) }\end{array}$ & $\begin{array}{c}\text { Average } \\
\text { Path } \\
\text { Distance } \\
\text { (GD) }\end{array}$ & $\begin{array}{c}\text { Modularity } \\
\text { (No. of } \\
\text { Modules) }\end{array}$ & $\begin{array}{c}\text { Average } \\
\text { Clustering } \\
\text { Coefficient } \\
\text { (avgCC) }\end{array}$ & $\begin{array}{c}\text { Average } \\
\text { Path } \\
\text { Distance } \\
\text { (GD) }\end{array}$ & $\begin{array}{c}\text { Modularity } \\
\text { (M) }\end{array}$ \\
\hline CK & 0.91 & 437 & 12.43 & 0.824 & 4.594 & $0.751(12)$ & $0.037 \pm 0.003$ & $2.694 \pm 0.005$ & $0.242 \pm 0.004$ \\
\hline F & 0.92 & 437 & 12.252 & 0.785 & 4.742 & $0.722(18)$ & $0.034 \pm 0.002$ & $2.725 \pm 0.009$ & $0.243 \pm 0.004$ \\
\hline CC & 0.91 & 387 & 10.098 & 0.827 & 5.607 & $0.772(12)$ & $0.035 \pm 0.003$ & $2.828 \pm 0.006$ & $0.273 \pm 0.005$ \\
\hline
\end{tabular}

The topological roles of the OTUs were visualized in the Z-P plot (Figure 7), and the keystone OTUs were plotted according to two parameters: within-module connectivity (Zi) and connectivity among modules (Pi). As shown in Figure 7, about $2.14 \%$ of the OTUs were module hubs, and about $0.32 \%$ OTUs were connectors. Nevertheless, there were no network hubs in the three networks. In the CK, F and CC treatments, the numbers of OTUs for the module hubs were 7,12 and 7, respectively; and the numbers of OTUs for the connectors were 2, 1 and 1, respectively. Apart from four unclassified OTUs, almost all module hubs belonged to Ascomycota only, with one belonging to Basidiomycota and one to Rozellomycota. Among the four connectors, two belonged to Basidiomycota, one to Ascomycota, and another one was unclassified. These results suggested that flooding and calcium cyanamide treatments influenced the topological roles and the putative keystone taxa, thus influencing the fungal community structure and integrity and the co-occurrence patterns. 


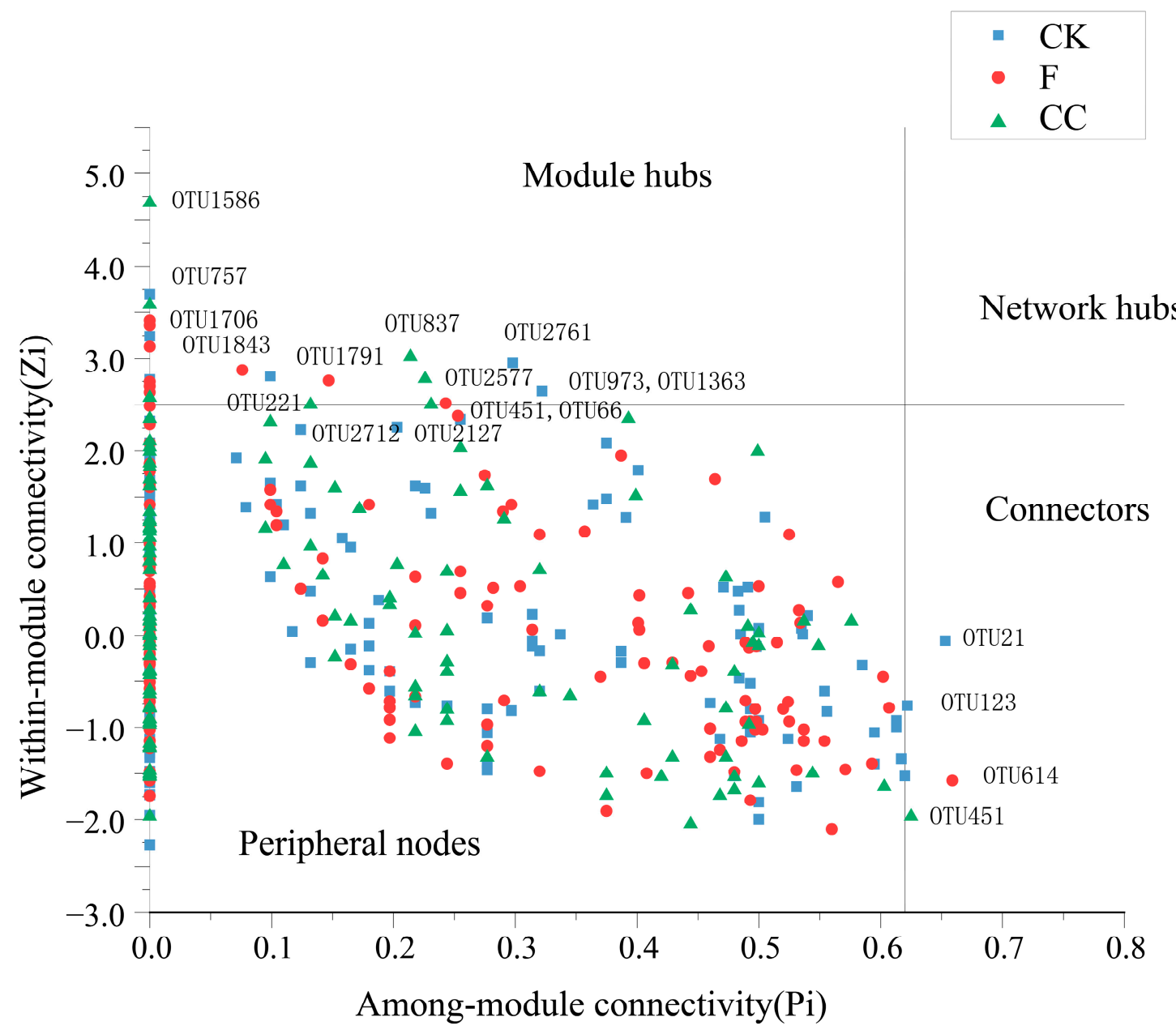

Figure 7. Z-P plot based on OTUs' topological roles. Each symbol represents an OTU in the CK (blue), F (red), and CC (green) treatments. The module hubs and connectors are labeled with OTU numbers.

\subsection{Functional Prediction of Soil Fungal Communities}

FUNGuild gave more detailed information on the trophic modes of fungal populations (Figure 8). The results (probable and highly probable) included 704 OTUs and showed that seven trophic mode groups could be classified. For all the three treatments, saprotrophy was the primary trophic mode, accounting for $78.87 \%, 83.74 \%$ and $82.32 \%$ in CK, F and $\mathrm{CC}$, respectively. According to the Guild analysis, undefined saprotroph was the most abundant guild in the saprotroph mode, being higher in the F and CC treatments $(61.14 \%$ and $62.64 \%)$ than the CK (57.59\%). Conversely, the Dung Saprotroph-Plant Saprotroph guild was in the following order: CK $(11.33 \%)>$ CC $(7.83 \%)>$ F $(5.86 \%)$. In addition, the symbiotrophic mode consisted primarily of the endophyte, arbuscular mycorrhizal, lichenized, and ectomycorrhizal groups. Endophyte decreased in the F and CC treatments $(0.77 \%$ and $1.04 \%)$ compared with the CK $(1.47 \%)$. The pathotrophic mode was detected in the three soil treatments. The ratios of plant pathogens were in the following order: $\mathrm{F}$ $(8.07 \%)>\mathrm{CK}(7.69 \%)>\mathrm{CC}(6.23 \%)$. However, the ratios of animal pathogens were in the reverse order: $\mathrm{F}(0.50 \%)<\mathrm{CK}(0.87 \%)<\mathrm{CC}(1.44 \%)$. We could infer that the $\mathrm{F}$ treatment decreased animal pathogens, but increased plant pathogens, whereas CC increased animal pathogens and decreased plant pathogens. 
(A)

Trophic Modes

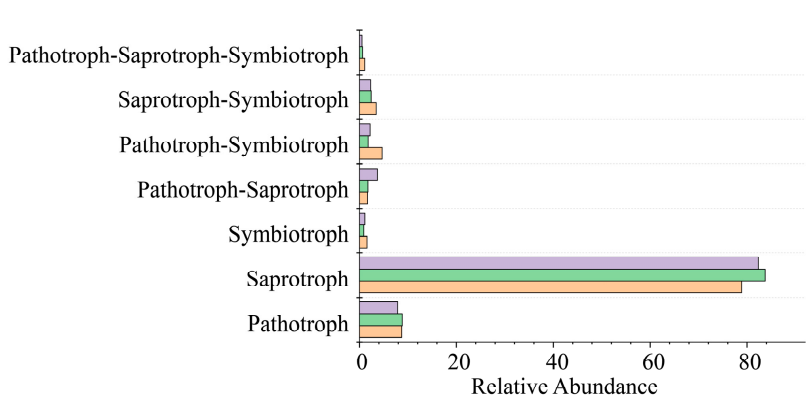

(C)

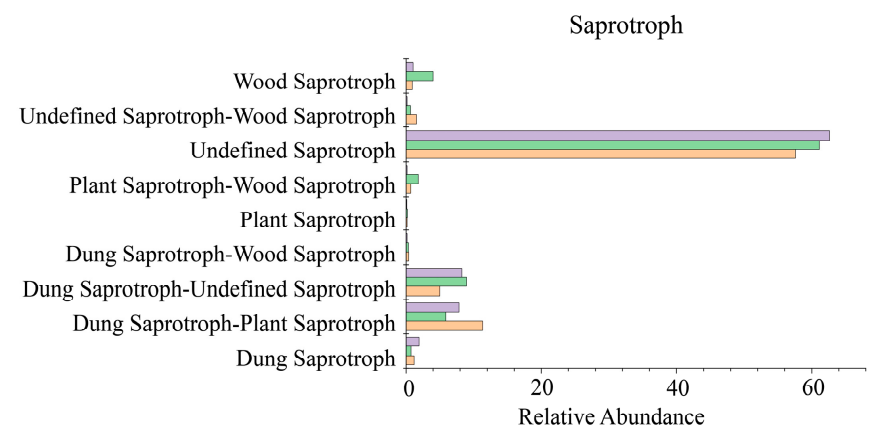

(B)

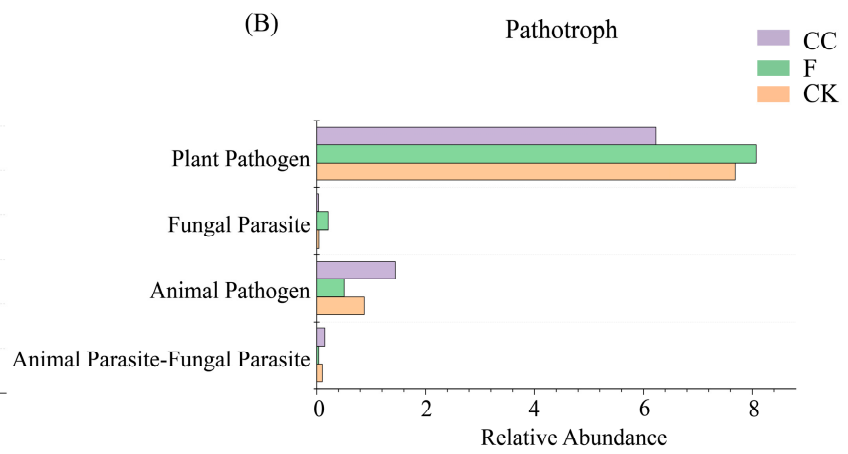

(D)

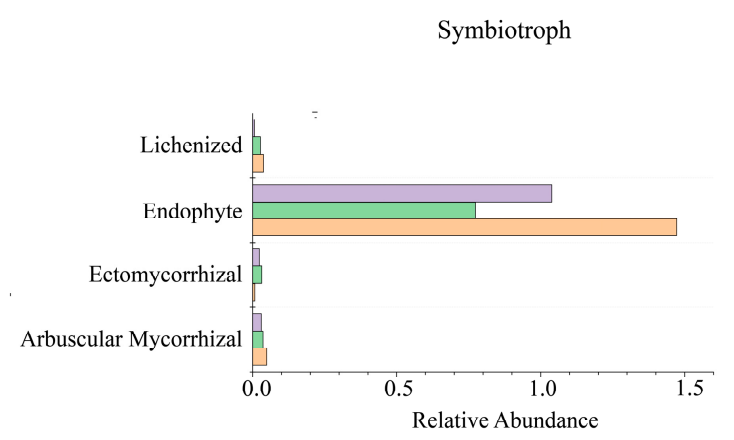

Figure 8. The relative abundance of trophic modes $(\mathbf{A})$ and the main guilds $(\mathbf{B}-\mathbf{D})$ in the soil fungal communities in the three treatments as assigned by FUNGuild.

\section{Discussion}

In our study, we observed low $\mathrm{pH}$, high polyphenols and high exchangeable aluminum and acid-soluble aluminum in the CK treatment. The treatment with calcium cyanamide significantly increased soil $\mathrm{pH}$ value and decreased the contents of exchangeable aluminum and total and bound phenols. This is because the $\mathrm{Ca}(\mathrm{OH})_{2}$ produced by the hydrolysis of calcium cyanamide neutralized soil acidity. With an increase in $\mathrm{pH}$, soluble aluminum in the soil wound complex with anions $\left(\mathrm{F}^{-}, \mathrm{PO}_{3}{ }^{-}, \mathrm{SO}_{4}{ }^{2-}\right.$, etc), which could explain the lower content of AP and Ex-Al in the F and CC treatments. The allelochemical activity of polyphenols and aluminum toxicity was closely associated with replanting disease in agricultural systems $[4,44]$. The present results indicated that calcium cyanamide could solve the growth obstacles in tea-cuttings nurseries by moderating soil $\mathrm{pH}$ and decreasing the concentrations of polyphenols and toxic aluminum. In addition, flooding and calcium cyanamide increased the survival rate of tea seedlings, which could be related to the improvement of the soil physiochemical properties.

Changes in soil physical and chemical properties cause a relatively quick response of soil microorganisms (fungi). Clustering and PCoA analysis revealed the changes in the fungal community composition. The results showed that the restructuring of fungal communities caused by the CC treatment occurred mainly at the lower taxonomic levels, because the dominant genera in different treatments were obviously different. Conversely, the composition of the dominant fungal phyla was similar across the treatments, whereas the composition ratio exhibited large variations. Ascomycota was the predominant phylum in tea nursery soil in the three treatments, with the strongest domination of Ascomycota in the CC treatment. It could be due to the capability of Ascomycota to tolerate stress conditions (such as low nutrient availability) [45]. The higher relative abundance of Ascomycota in the CC treatment could be related to the lower soil nutrient status. There were consistent results showing that $\mathrm{N}$ amendments or $\mathrm{N}$ fertilizers lead to a high relative abundance of Ascomycota and low relative abundance of Basidiomycota [46,47]; this could be another reason for fungi shifts in the calcium cyanamide treatment. The flooding treatment showed a lower relative abundance of aerobic fungi such as Ascomycota and Chytridiomycota, but a higher relative abundance of Basidiomycota and Rozellomycota compared with CK. These 
sensitive fungi could represent succession in fungal diversity, because flooding may change the composition of the fungal community rapidly by creating an anaerobic environment, thus causing significant shifts in the fungal community.

At the genus level, Trichoderma was found as the dominant genus mainly in the CK treatment. Trichoderma species are capable to protect plants from pathogen infections via several mechanisms, such as mycoparasitism, secondary metabolites, nutrient competition, enzymes, hyperparasitism, and induced systemic resistance (ISR) [48]. Mortierella species are thought to have the ability to degrade chitin and hemicellulose [49]; in addition, as phosphate-solubilizing fungus, Mortierella can also enhance the colonization by AMF (Arbuscular Mycorrhizal Fungi) and alleviate the effects of salt on plant growth and soil enzyme activities [50]. Mortierella was dominant in the CK treatment, and the relative abundance of Mortierella in the F treatment was close to that of CK (about 5.5\%), whereas it was lower in the CC treatment (2.8\%). Some species of Emericellopsis were reported as alkalophilic fungi [28], and we found them at a relatively high abundance $(7.72 \%)$ in the CC treatment. Talaromyces was one of the dominant genera in the CC treatment, accounting for $8.41 \%$ of the total; they were reported to solubilize phosphorus [51]. It could be beneficial fungi in the soils that have low phosphorus availability [28], thus increasing plant efficiency of phosphorus uptake.

Alpha diversity analysis showed that the calcium cyanamide treatment diminished the richness of fungal communities. This is simply because fungi is more sensitive to toxic calcium cyanamide [18]. Additionally, there was a report showing that the abundance of soil bacteria increased after calcium cyanamide application, whereas the abundance of fungi decreased [15]. It is likely that calcium cyanamide may restore the microbial community balance due to its different toxic extent for microbes [52].

In the network analysis, the structural community switched to a poorly connected (based on the GD, avgCC, and avgK parameters) and highly modularized (based on the modularity parameter) network in CC treatment. As the distribution of OTUs based on the topological roles shows, the OTUs of the CK, F and CC treatments were divided into peripheral nodes, module hubs and connectors. The module hubs and connectors could function as the keystone taxa, and if the OTUs from the keystone decreased sharply, the network would severely deteriorate or collapse $[53,54]$. However, the absence of peripheral nodes will not affect the functions of the ecological network $[55,56]$. The classification and related functions of the keystone taxa are summarized in Table 4, which revealed that more taxa related to root pathogens were found in the $\mathrm{CK}$, whereas more taxa related to anti-pathogenicity were found in the CC treatment. These findings suggest that, at least partially, the calcium cyanamide treatment hindered the signal, energy or matter transfer efficiency among fungal species [57]. In addition, it engendered a shift in the keystone OTUs, making the pathogens occupy a less important niche in the fungal community structure, whereas the taxa related to anti-pathogenicity occupied a more important niche, thus improving the soil quality.

FUNGuild was used to further explore the trophic modes in tea nursery soil. In our study, the CC treatment resulted in a higher proportion of saprotrophs compared with the CK. Sun et al. [58] concluded that the addition of nitrogen enhanced the growth of saprotrophic fungi and stimulated the decomposition of organic matters, which was consistent with the results of our study. Additionally, the CC treatment had a lower proportion of pathotrophs compared with the $\mathrm{CK}$, indicating that calcium cyanamide might decrease the risk of soil-borne fungal diseases.

Given the short-term duration of our study, the long-term effects of calcium cyanamide on continuous tea nurseries need to be clarified in further research. Due to the limitation of the sequencing data in this study, the differences in fungal community composition also might be attributed to the niche differentiation of fungi and bacteria. Calcium cyanamide application may increase soil bacterial abundance and decrease pathogenic fungi abundance according to Shi et al. [59]. Hence, in further work, we will focus on the effects of 
calcium cyanamide on bacterial and fungal communities and pay particular attention to the long-term effects.

Table 4. The classification and related functions of keystone taxa in the fungal network.

\begin{tabular}{|c|c|c|c|c|}
\hline Treatment & Keystones OTU Name & Classification & Related Functions & References \\
\hline \multirow{9}{*}{ CK } & OTU757 & s_Aspergillus_chlamydosporus & $\begin{array}{l}\text { halophilic and } \\
\text { halotolerant fungi }\end{array}$ & {$[60]$} \\
\hline & OTU953 & s_Coniochaeta_fasciculata & $\begin{array}{c}\text { Canker and wood rot } \\
\text { pathogens }\end{array}$ & [61] \\
\hline & OTU221 & s_Leucosporidium_golubevii & psychrotolerant & {$[62]$} \\
\hline & OTU1295 & s_Neocosmospora_rubicola & Causing stem rot & [63] \\
\hline & OTU1363 & s_Setophoma_sp & $\begin{array}{l}\text { Some depsides showed } \\
\text { moderate antibacterial activity } \\
\text { against Gram-positive bacteria }\end{array}$ & {$[64]$} \\
\hline & OTU973 & s_unclassified_g_Colletotrichum & anthracnose pathogen & [65] \\
\hline & OTU2761 & s_unclassified_o_Pleosporales & Function unknown & \\
\hline & OTU21 & s_unclassified_k_Fungi & Function unknown & \\
\hline & OTU1123 & s_unclassified_f_Cyphellaceae & Function unknown & \\
\hline \multirow{13}{*}{$\mathrm{F}$} & OTU1706 & s_Westerdykella_purpurea & $\begin{array}{l}\text { Antagonist to agricultural } \\
\text { pathogenic fungi }\end{array}$ & [66] \\
\hline & OTU1843 & s_Arachnomyces_sp & Function unknown & \\
\hline & OTU1791 & s_Biatriospora_sp & antifungal activity & {$[67]$} \\
\hline & OTU1204 & s_Rozellomycota_sp & Function unknown & \\
\hline & OTU1279 & s_unclassified_g_Calonectria & $\begin{array}{l}\text { blight and crown and root rot } \\
\text { pathogens }\end{array}$ & [68] \\
\hline & OTU1813 & s_unclassified_k_Fungi & $\begin{array}{l}\text { promising sources of } \\
\text { hemicellulases }\end{array}$ & [69] \\
\hline & OTU26 & s_unclassified_o_Onygenales & Function unknown & \\
\hline & OTU2420 & s_unclassified_g_Talaromyces & Function unknown & \\
\hline & OTU1594 & s_unclassified_k_Fungi & Function unknown & \\
\hline & OTU1893 & s_unclassified_g_Acaulium & Function unknown & \\
\hline & OTU451 & s_unclassified_p_Ascomycota & Function unknown & \\
\hline & OTU66 & s_unclassified_k_Fungi & Function unknown & \\
\hline & OTU614 & s_unclassified_o_Hymenochaetales & Function unknown & \\
\hline \multirow{9}{*}{$\mathrm{CC}$} & OTU837 & s_Neocosmospora_ramosa & ability of biodeterioration & [70] \\
\hline & OTU503 & s_Setophoma_sp & $\begin{array}{l}\text { Some depsides showed } \\
\text { moderate antibacterial activity } \\
\text { against Gram-positive bacteria }\end{array}$ & [64] \\
\hline & OTU2712 & s_Pseudogymnoascus_sp & $\begin{array}{l}\text { some metabolites showed } \\
\text { antibacterial and } \\
\text { antifungal activities }\end{array}$ & [71] \\
\hline & OTU2127 & s_unclassified_g_Westerdykella & $\begin{array}{l}\text { Antagonist to agricultural } \\
\text { pathogenic fungi }\end{array}$ & {$[66]$} \\
\hline & OTU1586 & s_unclassified_k_Fungi & Function unknown & \\
\hline & OTU2046 & s_unclassified_c_Agaricomycetes & Function unknown & \\
\hline & OTU2577 & s_unclassified_o_Sordariales & Function unknown & \\
\hline & OTU88 & s_unclassified_o_Xylariales & Function unknown & \\
\hline & OTU451 & s_unclassified_p_Ascomycota & Function unknown & \\
\hline
\end{tabular}




\section{Conclusions}

The application of calcium cyanamide and flooding had some effect on alleviating the soil obstacles and increasing the survival rate of tea seedlings in tea-cuttings nurseries. Moreover, calcium cyanamide should be recommended for improving successive tea nurseries, as it can improve the survival rate of tea seedlings mainly by increasing soil $\mathrm{pH}$ value, decreasing aluminum toxicity, reducing the accumulation of polyphenols, diminishing pathogenic fungi, and making the taxa related to anti-pathogenicity occupy a more important niche. All these changes may promote the growth of tea seedlings; however, because of the short-term duration of our study, long-term experiments are needed to explore further the effects of calcium cyanamide in the tea nursery soils.

Supplementary Materials: The following are available online at https:/ /www.mdpi.com/article/10.3 390/agriculture11080716/s1, Table S1: Coverage index of soil fungal community in different treatments.

Author Contributions: Conceptualization, Q.Q. and X.W.; formal analysis, Q.Q. and Y.W. (Yu Wang); resources, D.F., J.M. and Y.W. (Yinmao Wang); data curation, Q.Q. and D.F.; writing—original draft preparation, Q.Q.; writing - review and editing, D.H., Q.Q. and X.W.; supervision, X.W. All authors have read and agreed to the published version of the manuscript.

Funding: This research was funded by the collaborative promotion of major agricultural technology in Zhejiang Province (2018XTTGCY01-6 and 2018XTTGCY01-3), Lishui science and technology project (LS2016000x) and Lishui City Science and Technology Project(2020TPY31).

Data Availability Statement: The data presented in this study are available on request from the corresponding author.

Conflicts of Interest: The authors declare no conflict of interest.

\section{References}

1. Arafat, Y.; Tayyab, M.; Khan, M.U.; Chen, T.; Amjad, H.; Awais, S.; Lin, X.M.; Lin, W.X.; Lin, S. Long-Term Monoculture Negatively Regulates Fungal Community Composition and Abundance of Tea Orchards. Agronomy 2019, 9, 466. [CrossRef]

2. Li, Y.C.; Li, Z.W.; Arafat, Y.; Lin, W.X. Studies on fungal communities and functional guilds shift in tea continuous cropping soils by high-throughput sequencing. Ann. Microbiol. 2020, 70, 1-12. [CrossRef]

3. Li, Y.C.; Li, Z.; Li, Z.W.; Jiang, Y.H.; Weng, B.Q.; Lin, W.X. Variations of rhizosphere bacterial communities in tea (Camellia sinensis L.) continuous cropping soil by high-throughput pyrosequencing approach. J. Appl. Microbiol. 2016, 121, 787-799. [CrossRef] [PubMed]

4. Wang, H.; Xu, R.K.; Wang, N.; Li, X.H. Soil Acidification of Alfisols as Influenced by Tea Cultivation in Eastern China. Pedosphere 2010, 20, 799-806. [CrossRef]

5. Bai, Y.; Wang, G.; Cheng, Y.; Shi, P.; Yang, C.; Yang, H.; Xu, Z. Soil acidification in continuously cropped tobacco alters bacterial community structure and diversity via the accumulation of phenolic acids. Sci. Rep. 2019, 9, 12499. [CrossRef]

6. Ye, J.H.; Wang, H.B.; Yang, X.Y.; Zhang, Q.; Li, J.Y.; Jia, X.L.; Kong, X.H.; He, H.B. Autotoxicity of the soil of consecutively cultured tea plantations on tea (Camellia sinensis) seedlings. Acta Physiol. Plant. 2016, 38, 195. [CrossRef]

7. Fan, D.M.; Fan, K.; Yu, C.P.; Lu, Y.T.; Wang, X.C. Tea polyphenols dominate the short-term tea (Camellia sinensis) leaf litter decomposition. J. Zhejiang Univ. Sci. B 2017, 18, 99-108. [CrossRef] [PubMed]

8. Zhou, X.; Wu, F. p-Coumaric acid influenced cucumber rhizosphere soil microbial communities and the growth of Fusarium oxysporum f.sp. cucumerinum Owen. PLoS ONE 2012, 7, e48288. [CrossRef]

9. Feng, Y.; Motta, A.C.; Reeves, D.W.; Burmester, C.H.; van Santen, E.; Osborne, J.A. Soil microbial communities under conventionaltill and no-till continuous cotton systems. Soil Biol. Biochem. 2003, 35, 1693-1703. [CrossRef]

10. Lu, L.; Yin, S.; Liu, X.; Zhang, W.; Gu, T.; Shen, Q.; Qiu, H. Fungal networks in yield-invigorating and -debilitating soils induced by prolonged potato monoculture. Soil Biol. Biochem. 2013, 65, 186-194. [CrossRef]

11. Nicola, L.; Turco, E.; Albanese, D.; Donati, C.; Thalheimer, M.; Pindo, M.; Insam, H.; Cavalieri, D.; Pertot, I. Fumigation with dazomet modifies soil microbiota in apple orchards affected by replant disease. Appl. Soil Ecol. 2017, 113, 71-79. [CrossRef]

12. Benizri, E.; Piutti, S.; Verger, S.; Pagès, L.; Vercambre, G.; Poessel, J.L.; Michelot, P. Replant diseases: Bacterial community structure and diversity in peach rhizosphere as determined by metabolic and genetic fingerprinting. Soil Biol. Biochem. 2005, 37, 1738-1746. [CrossRef]

13. Lin, W.; Wu, L.; Lin, S.; Zhang, A.; Zhou, M.; Lin, R.; Wang, H.; Chen, J.; Zhang, Z.; Lin, R. Metaproteomic analysis of ratoon sugarcane rhizospheric soil. BMC Microbiol. 2013, 13, 135. [CrossRef]

14. Dixon, G.R. Managing clubroot disease (caused by Plasmodiophora brassicae Wor.) by exploiting the interactions between calcium cyanamide fertilizer and soil microorganisms. J. Agric. Sci. 2016, 155, 527-543. [CrossRef] 
15. Ma, J.; Sun, W.; Hu, Q.; Yu, Q.; Wang, Q.; Fu, J. Effects of cyanamide fertiliser on microbial community structure of continuous cropping soil. J. Zhejiang Univ. Agric. Life Sci. 2013, 39, 281-290.

16. Oh, K.; Kato, T.; Li, Z.-P.; Li, F.-Y. Environmental Problems From Tea Cultivation in Japan and a Control Measure Using Calcium Cyanamide. Pedosphere 2006, 16, 770-777. [CrossRef]

17. Chai, A.L.; Xie, X.W.; Shi, Y.X.; Li, B.J. Research status of clubroot (Plasmodiophora brassicae) on cruciferous crops in China. Can. J. Plant Pathol. 2014, 36 (Suppl. 1), 142-153. [CrossRef]

18. Bourbos, V.A.; Skoudridakis, M.T.; Darakis, G.A.; Koulizakis, M. Calcium cyanamide and soil solarization for the control of Fusarium solani f.sp. cucurbitae in greenhouse cucumber. Crop Prot. 1997, 16, 383-386. [CrossRef]

19. Liu, S.C.; Tang, L.Z.; Shi, Q.; Yi, Z.X.; Zhou, W.X. Progress on application of calcium cyanamide in agricultural production. Soil Fertil. Sci. China 2017, 4, 1-6.

20. Hou, Y.L. Experimental Study of Potassium Nitrate and Calcium Cyanamide on Breaking Natural Dormancy of Apple and Grape. J. Anhui Agric. Sci. 2008, 36, 13612-13617.

21. Dixon, G.R. Calcium Cyanamide-A Synoptic Review of an Environmentally Benign Fertiliser Which Enhances Soil Health. Acta Hortic. 2012, 938, 211-217. [CrossRef]

22. Wu, Q.F.; Xu, Q.F.; Qin, H.; Zhang, J.L.; Qian, M.; Qian, J.W. Effects of calcium cyanamide on soil microbial properties of intensively managed Phyllostachys violascens stands. J. Zhejiang Univ. 2014, 31, 352-357.

23. Belec, C.; Tremblay, N.; Coulombe, J. Liming and calcium cyanamid for clubroot control in cauliflower. Acta Hortic. 2004, 635, 41-46. [CrossRef]

24. Strauss, S.L.; Greenhut, R.F.; McClean, A.E.; Kluepfel, D.A. Effect of anaerobic soil disinfestation on the bacterial community and key soilborne phytopathogenic agents under walnut tree-crop nursery conditions. Plant Soil 2017, 415, 493-506. [CrossRef]

25. Khadka, R.B.; Marasini, M.; Rawal, R.; Testen, A.L.; Miller, S.A. Effects of anaerobic soil disinfestation carbon sources on soilborne diseases and weeds of okra and eggplant in Nepal. Crop Prot. 2020, 135, 104846. [CrossRef]

26. Tedersoo, L.; Bahram, M.; Polme, S.; Koljalg, U.; Yorou, N.S.; Wijesundera, R.; Ruiz, L.V.; Vasco-Palacios, A.M.; Thu, P.Q.; Suija, A.; et al. Fungal biogeography. Global diversity and geography of soil fungi. Science 2014, 346, 1256688. [CrossRef]

27. Jones, M.D.; Forn, I.; Gadelha, C.; Egan, M.J.; Bass, D.; Massana, R.; Richards, T.A. Discovery of novel intermediate forms redefines the fungal tree of life. Nature 2011, 474, 200-203. [CrossRef]

28. Devi, R.; Kaur, T.; Kour, D.; Rana, K.L.; Yadav, A.; Yadav, A.N. Beneficial fungal communities from different habitats and their roles in plant growth promotion and soil health. Microb. Biosyst. 2020, 5, 21-47. [CrossRef]

29. De Gannes, V.; Eudoxie, G.; Hickey, W.J. Insights into fungal communities in composts revealed by 454-pyrosequencing: Implications for human health and safety. Front. Microbiol. 2013, 4, 164. [CrossRef] [PubMed]

30. Peng, J.; Wang, K.; Yin, X.B.; Yin, X.Q.; Du, M.F.; Gao, Y.Z.; Antwi, P.; Ren, N.Q.; Wang, A.J. Trophic mode and organics metabolic characteristic of fungal community in swine manure composting. Front. Environ. Sci. Eng. 2019, 13, 93. [CrossRef]

31. Rousk, J.; Baath, E.; Brookes, P.C.; Lauber, C.L.; Lozupone, C.; Caporaso, J.G.; Knight, R.; Fierer, N. Soil bacterial and fungal communities across a pH gradient in an arable soil. ISME J. 2010, 4, 1340-1351. [CrossRef]

32. Nguyen, N.H.; Song, Z.; Bates, S.T.; Branco, S.; Tedersoo, L.; Menke, J.; Schilling, J.S.; Kennedy, P.G. FUNGuild: An open annotation tool for parsing fungal community datasets by ecological guild. Fungal Ecol. 2016, 20, 241-248. [CrossRef]

33. Eldridge, D.J.; Delgado-Baquerizo, M. Functional groups of soil fungi decline under grazing. Plant Soil 2018, 426, 51-60. [CrossRef]

34. Anthony, M.A.; Frey, S.D.; Stinson, K.A. Fungal community homogenization, shift in dominant trophic guild, and appearance of novel taxa with biotic invasion. Ecosphere 2017, 8, e01951. [CrossRef]

35. Igiehon, N.O.; Babalola, O.O. Biofertilizers and sustainable agriculture: Exploring arbuscular mycorrhizal fungi. Appl. Microbiol. Biotechnol. 2017, 101, 4871-4881. [CrossRef] [PubMed]

36. Rouphael, Y.; Franken, P.; Schneider, C.; Schwarz, D.; Giovannetti, M.; Agnolucci, M.; Pascale, S.D.; Bonini, P.; Colla, G. Arbuscular mycorrhizal fungi act as biostimulants in horticultural crops. Sci. Hortic. 2015, 196, 91-108. [CrossRef]

37. Che, R.; Wang, S.; Wang, Y.; Xu, Z.; Wang, W.; Rui, Y.; Wang, F.; Hu, J.; Tao, J.; Cui, X. Total and active soil fungal community profiles were significantly altered by six years of warming but not by grazing. Soil Biol. Biochem. 2019, 139, 107611. [CrossRef]

38. Li, P.F.; Liu, J.; Jiang, C.Y.; Wu, M.; Liu, M.; Wei, S.P.; Qiu, C.P.; Li, G.L.; Xu, C.X.; Li, Z.P. Trade-off between potential phytopathogenic and non-phytopathogenic fungi in the peanut monoculture cultivation system. Appl. Soil Ecol. 2020, 148, 103508. [CrossRef]

39. Roper, W.R.; Robarge, W.P.; Osmond, D.L.; Heitman, J.L. Comparing Four Methods of Measuring Soil Organic Matter in North Carolina Soils. Soil Sci. Soc. Am. J. 2019, 83, 466-474. [CrossRef]

40. Zhang, M.; Fan, D.M.; Zhu, Q.; Luo, Y.P.; Wang, X.C. Contribution of High Accumulated Polyphenols to C Stabilization in Soil of Tea Gardens. In Functions of Natural Organic Matter in Changing Environment; Springer: Dordrecht, The Netherlands, 2013; pp. 397-400.

41. Adams, R.I.; Miletto, M.; Taylor, J.W.; Bruns, T.D. Dispersal in microbes: Fungi in indoor air are dominated by outdoor air and show dispersal limitation at short distances. ISME J. 2013, 7, 1262-1273. [CrossRef] [PubMed]

42. Deng, Y.; Jiang, Y.H.; Yang, Y.; He, Z.; Luo, F.; Zhou, J. Molecular ecological network analyses. BMC Bioinform. $2012,13,113$. [CrossRef] [PubMed]

43. Zhou, J.; Deng, Y.; Luo, F.; He, Z.; Yang, Y. Phylogenetic molecular ecological network of soil microbial communities in response to elevated $\mathrm{CO}_{2}$. mBio 2011, 2, e00122-11. [CrossRef] [PubMed] 
44. Arafat, Y.; Din, I.U.; Tayyab, M.; Jiang, Y.; Chen, T.; Cai, Z.; Zhao, H.; Lin, X.; Lin, W.; Lin, S. Soil Sickness in Aged Tea Plantation Is Associated with a Shift in Microbial Communities as a Result of Plant Polyphenol Accumulation in the Tea Gardens. Front. Plant Sci. 2020, 11, 601. [CrossRef] [PubMed]

45. Chen, Y.-L.; Xu, T.-L.; Veresoglou, S.D.; Hu, H.-W.; Hao, Z.-P.; Hu, Y.-J.; Liu, L.; Deng, Y.; Rillig, M.C.; Chen, B.-D. Plant diversity represents the prevalent determinant of soil fungal community structure across temperate grasslands in northern China. Soil Biol. Biochem. 2017, 110, 12-21. [CrossRef]

46. Nemergut, D.R.; Townsend, A.R.; Sattin, S.R.; Freeman, K.R.; Fierer, N.; Neff, J.C.; Bowman, W.D.; Schadt, C.W.; Weintraub, M.N.; Schmidt, S.K. The effects of chronic nitrogen fertilization on alpine tundra soil microbial communities: Implications for carbon and nitrogen cycling. Environ. Microbiol. 2008, 10, 3093-3105. [CrossRef]

47. Paungfoo-Lonhienne, C.; Yeoh, Y.K.; Kasinadhuni, N.R.; Lonhienne, T.G.; Robinson, N.; Hugenholtz, P.; Ragan, M.A.; Schmidt, S. Nitrogen fertilizer dose alters fungal communities in sugarcane soil and rhizosphere. Sci. Rep. 2015, 5, 8678. [CrossRef]

48. Saravanakumar, K.; Wang, M.H. Isolation and molecular identification of Trichoderma species from wetland soil and their antagonistic activity against phytopathogens. Physiol. Mol. Plant Pathol. 2020, 109, 101458. [CrossRef]

49. Kim, Y.J.; Yong, Z.; Oh, K.T.; Nguyen, V.N.; Park, R.D. Enzymatic deacetylation of chitin by extracellular chitin deacetylase from a newly screened Mortierella sp. DY-52. J. Microbiol. Biotechnol. 2008, 18, 759-766.

50. Zhang, H.S.; Wu, X.H.; Li, G.; Qin, P. Interactions between arbuscular mycorrhizal fungi and phosphate-solubilizing fungus (Mortierella sp.) and their effects on Kostelelzkya virginica growth and enzyme activities of rhizosphere and bulk soils at different salinities. Biol. Fertil. Soils 2011, 47, 543-554. [CrossRef]

51. Zhang, Y.; Chen, F.S.; Wu, X.Q.; Luan, F.G.; Zhang, L.P.; Fang, X.M.; Wan, S.Z.; Hu, X.F.; Ye, J.R. Isolation and characterization of two phosphate-solubilizing fungi from rhizosphere soil of moso bamboo and their functional capacities when exposed to different phosphorus sources and $\mathrm{pH}$ environments. PLoS ONE 2018, 13, e0199625. [CrossRef]

52. Tayyab, M.; Islam, W.; Lee, C.G.; Pang, Z.Q.; Khalil, F.; Lin, S.; Lin, W.X.; Zhang, H. Short-Term Effects of Different Organic Amendments on Soil Fungal Composition. Sustainability 2019, 11, 198. [CrossRef]

53. Liao, H.; Zhang, Y.C.; Wang, K.; Hao, X.L.; Chen, W.L.; Huang, Q.Y. Complexity of bacterial and fungal network increases with soil aggregate size in an agricultural Inceptisol. Appl. Soil Ecol. 2020, 154, 103640. [CrossRef]

54. Olesen, J.M.; Bascompte, J.; Dupont, Y.L.; Jordano, P. The modularity of pollination networks. Proc. Natl. Acad. Sci. USA 2007, 104, 19891-19896. [CrossRef]

55. Ramos-Jiliberto, R.; Valdovinos, F.S.; de Espanes, P.M.; Flores, J.D. Topological plasticity increases robustness of mutualistic networks. J. Anim. Ecol. 2012, 81, 896-904. [CrossRef]

56. Kaiser-Bunbury, C.N.; Muff, S.; Memmott, J.; Muller, C.B.; Caflisch, A. The robustness of pollination networks to the loss of species and interactions: A quantitative approach incorporating pollinator behaviour. Ecol. Lett. 2010, 13, 442-452. [CrossRef]

57. Peura, S.; Bertilsson, S.; Jones, R.I.; Eiler, A. Resistant microbial cooccurrence patterns inferred by network topology. Appl. Environ. Microbiol. 2015, 81, 2090-2097. [CrossRef] [PubMed]

58. Sun, R.; Dsouza, M.; Gilbert, J.A.; Guo, X.; Wang, D.; Guo, Z.; Ni, Y.; Chu, H. Fungal community composition in soils subjected to long-term chemical fertilization is most influenced by the type of organic matter. Environ. Microbiol. 2016, 18, 5137-5150. [CrossRef]

59. Shi, K.; Wang, L.; Zhou, Y.H.; Yu, Y.L.; Yu, J.Q. Effects of calcium cyanamide on soil microbial communities and Fusarium oxysporum f. sp. cucumberinum. Chemosphere 2009, 75, 872-877. [CrossRef]

60. Martinelli, L.; Zalar, P.; Gunde-Cimerman, N.; Azua-Bustos, A.; Sterflinger, K.; Pinar, G. Aspergillus atacamensis and A. salisburgensis: Two new halophilic species from hypersaline/arid habitats with a phialosimplex-like morphology. Extremophiles 2017, 21, 755-773. [CrossRef]

61. Havenga, M.; Gatsi, G.M.; Halleen, F.; Spies, C.F.J.; van der Merwe, R.; Mostert, L. Canker and Wood Rot Pathogens Present in Young Apple Trees and Propagation Material in the Western Cape of South Africa. Plant Dis. 2019, 103, 3129-3141. [CrossRef]

62. Sampaio, J.P.; Fell, L.; Statzell, I.L. Hunter \& Phaff (1969). In The Yeasts; Elsevier: London, UK, 2011; pp. 1485-1494.

63. Zheng, F.; Xu, G.; Zheng, F.Q.; Ding, X.F.; Xie, C.P. Neocosmospora rubicola Causing Stem Rot of Pitaya (Hylocereus costaricensis) in China. Plant Dis. 2018, 102, 2653. [CrossRef]

64. de Medeiros, L.S.; Abreu, L.M.; Nielsen, A.; Ingmer, H.; Larsen, T.O.; Nielsen, K.F.; Rodrigues-Filho, E. Dereplication-guided isolation of depsides thielavins S-T and lecanorins D-F from the endophytic fungus Setophoma sp. Phytochemistry 2015, 111, 154-162. [CrossRef] [PubMed]

65. Wang, Q.-H.; Ji, Y.-P.; Qu, Y.-Y.; Qi, Y.-K.; Li, D.-W.; Liu, Z.-Y.; Wu, X.-Q. The response strategies of Colletotrichum gloeosporioides s.s. due to the stress caused by biological control agent Bacillus amyloliquefaciens deciphered by transcriptome analyses. Biol. Control 2020, 150, 104372. [CrossRef]

66. Xu, D.; Pang, X.J.; Zhao, T.; Xu, L.L.; Yang, X.L. New alkenylated tetrahydropyran derivatives from the marine sediment-derived fungus Westerdykella dispersa and their bioactivities. Fitoterapia 2017, 122, 45-51. [CrossRef]

67. Zhou, Y.H.; Zhang, M.; Zhu, R.X.; Zhang, J.Z.; Xie, F.; Li, X.B.; Chang, W.Q.; Wang, X.N.; Zhao, Z.T.; Lou, H.X. Heptaketides from an Endolichenic Fungus Biatriospora sp. and Their Antifungal Activity. J. Nat. Prod. 2016, 79, 2149-2157. [CrossRef] [PubMed]

68. Bartíková, M.; Holková, L.; Šafránková, I. Occurrence of boxwood blight (Calonectria pseudonaviculata and C. henricotiae) in historical gardens in the Czech Republic. Eur. J. Plant Pathol. 2020, 158, 135-142. [CrossRef] 
69. Mendez-Liter, J.A.; de Eugenio, L.I.; Nieto-Dominguez, M.; Prieto, A.; Martinez, M.J. Hemicellulases from Penicillium and Talaromyces for lignocellulosic biomass valorization: A review. Bioresour. Technol. 2021, 324, 124623. [CrossRef]

70. Aduroja, E.D.; Moore, G.G.; Beltz, S.B.; Soares, C.; Lima, N.; Fapohunda, S.O. Induction of biodeterioration on vegetables by three fungal species. J. Plant Pathol. 2018, 101, 243-250. [CrossRef]

71. Figueroa, L.; Jimenez, C.; Rodriguez, J.; Areche, C.; Chavez, R.; Henriquez, M.; de la Cruz, M.; Diaz, C.; Segade, Y.; Vaca, I. 3-Nitroasterric Acid Derivatives from an Antarctic Sponge-Derived Pseudogymnoascus sp. Fungus. J. Nat. Prod. 2015, 78, 919-923. [CrossRef] 